\title{
BREVE COMENTÁRIO DO XII ENCONTRO NACIONAL DE GEÓGRAFOS EM FLORIANÓPOLIS - SANTA CATARINA
}

\author{
Anselmo Alfredo
}

Se o frio de Florianópolis marcou de modo inconfundivel este XII ENG (Outros 500 na Formação do Território Brasileiro), inclusive para os catarinenses, não se pode negar que, como contrapeso, uma certa disposição para o debate ajudou a esquentar o clima dos geógrafos. Foi esta vontade de discutir os diversos temas abordados pelas apresentaçōes que motivou a Geografia Brasileira ao longo de toda semana de 16 a 23 de julho de 2000 no gélido sul do país. Neste sentido, se como nos diz Guy Debord, a "Sociedade do Espetáculo" coloca os agentes na condiçāo de passivos diante de um mundo que passa a ser representado, a semana geográfica nacional, dentro do possivel, suspendeu a representaçāo do mundo como abstraçāo que se concretiza. Fez ela o seu próprio caminho. As apresentaçōes de maior monta que poderiam espetacularizar o conhecimento - como as mesas redondas, por exemplo, viram-se obrigadas a debater com questōes que permitiam a construçāo do conhecimento in locu. Nada estava definido a priori.

Esta foi, talvez, uma boa colheita pela manutençāo dos Espaços de Diálogos no lugar das antigas "apresentaçōes livres" Torna-se inevitável que no turno da manhā os trabalhos passem por um processo de discussāo que envolve argumentos tanto a favor quanto contra as perspectivas abordadas nos diferentes estudos apresentados. Este estímulo matinal talvez tenha repercutido ao longo de todos os dias no encontro. Isto nāo quer dizer, evidentemente, que tudo ocor- reu sem problemas. O aconchegante, porém pequeno, espaço da UFSC (Universidade Federal de Santa Catarina) pequeno, é bem verdade, para um dos maiores encontros científicos brasileiros exigiu da organizaçāo uma adaptaçāo que em certos casos nāo foi benéfica ao Encontro como um todo. Os Espaços de Diálogos (EDs), por exemplo, proposta extremamente pertinente para um encontro cuja duração se estende por uma semana, viram-se obrigados a acolher um número de apresentaçōes bastante grande; além disso, houveram aqueles EDs que tiveram temáticas dispares, o que em ambos os casos dificultou uma troca maior entre os pesquisadores. Se os EDs são uma proposta pertinente ao debate, é fundamental que as temáticas sejam bem selecionadas e que nāo haja, em nenhum deles, sobrecarga de trabalhos a serem apresentados. Estes EDs só tèm sentido dentro de uma condição que permita a realização de seu objetivo: $o$ diálogo.

Devemos recordar também que na chegada do primeiro dia do Encontro duas enormes filas se formaram, onde cada participante deveria enfrentar as duas caso quisesse estar inscrito no encontro - o que acabou por tomar o dia todo. Ao final do encontro novas filas se formavam para retirada dos certificados e para refazer aqueles certificados cujo nome do participante aparecia errado. Neste último caso, voltava-se à espera de algumas horas (de très a quatro horas). É que para realizar a reimpressāo de centenas de certi- 
ficados o Encontro dispunha de apenas uma impressora. Neste sentido, esta experiência deve ser levada em consideraçāo para que o próximo seja ainda melhor. Afinal, após longa viagem ou após um encontro ao longo de toda uma semana, tudo o que se espera é não enfrentar fila nenhuma, quanto mais duas...

É oportuno lembrar, também, que durante a tarde houveram várias mesas concomitantes e com temáticas diferenciadas, o que contribuiu grandemente para que os participantes estivessem em apresentaçōes de seu interesse sem pena daquilo que náo estavam assistindo. O Encontro, enfim, conseguiu contemplar esta diversidade temática que é típica da própria pesquisa.

O XII Encontro Nacional de Geógrafos. enfim, contribuiu para reforçar a importáncia do encontro cientifico não apenas na difusão do conhecimento, mas contribuiu para estimular a continuidade do desenvolvimento da pesquisa científica no Brasil, em evidente contraposição a um momento em que tal pesquisa passa por um processo de restrição de possibilidades. Esta conquista nos é inalienável.

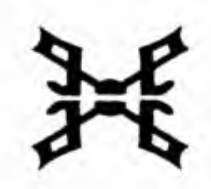

